Omar H AL-Luazy BDS, MSc (Lec.)

\title{
Effect of Lace Back on Amount of An- chorage Loss Using Labial and Lingual Technique. (An in vitro Study)
}

Dept of Pedod, Orthod and Prev Dentistry College of Dentistry, University of Mosul

الخحلاصة

الأهداف: لتقييم الأسنان الخلفية "الضاحك الثاني ، والطاحن الاول" عند استخدامها كمرساة داعمة في سحب الأنياب بطريقة الرابط الخلفي، بعد قلع الضرس الرابع

في حالات الازدحام الشديد للأسنان. ألمواد و طرائق العمل : بحموعتين من الحاصرات التقيمية أحداهما تقليدي"شفاهي" تثبت على المقطع ألشفاهي لكل الأسنان

المعدنية لمثيلي الأسنان التشابهي، باستثناء الضرس الرابع على الجانبين. وتثبت الحاصرات بلاصق خاص. والمحموعة الأخرى حاصرات لسانية تثبت بنفس الطريقة وعلى الطي

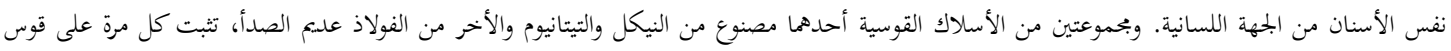

الأسنان وتسحب الأنياب من الجانبين، مرة بالطريقة الشفاهية ، وأخرى باللسانية. ويتم سحب الأنياب بالطريقة الانزلاقية الاحتكاكية، باستخدام حلقة بلاستيكية

متداخلة، مع سلك ملتف من الفولاذ. النتائج : أظهرت الدراسة انه لا يوجد فرقآ معنويآ عند استخدام السلك الفولاذي العديم الصدأ في كلتا الطريقتين "الشفاهية

التقليدية واللسانية" وظهرت فرقآ معنويآ عند استخدام السلك المصنوع من النيكل والتيتانيوم في الأسلوب اللساني، عندما قورن مع مثيله المستخدم في الطريقة التقليدية

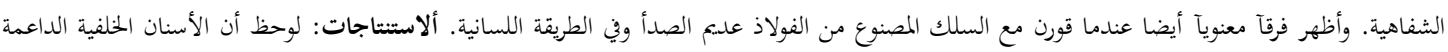

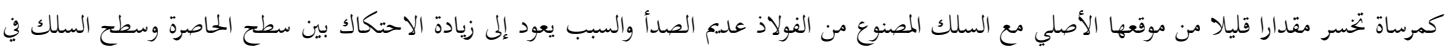

كالا الأسلوبين التقليدي واللساني. ويزداد ما تخسره الأسنان الداعمة كمرساة من مكاها الأصلي مع السلك المصنوع من النيكل تيتانيوم وخاصة في الأسلوب اللساني.

\section{ABSTRACT}

Aims: Evaluate the amount of anchorage loss of the lower posterior teeth 2 nd premolar and first molar when used as anchorage teeth for retraction of canine bilaterally by using lace back technique after extraction of first premolar in sever crowding cases. Materials and Methods: Two groups of brackets, one of them labial (conventional) were bonded on the labial aspect of metal teeth except $4 \mid 4$ typodont by special adhesive and other groups lingual brackets also bonded in the same teeth lingual surface and two types of light or low gauge arch wire Niti , twisted multi strand for sliding the canines retraction by using elastomeric ring with ligature wire active lace back once with labial and other with lingual technique. Results: There is no significant difference between twisted multi strand wire when ligated on the teeth in both lingual technique and labial technique. Significant difference when used Niti wire on lingual technique when compared with the same type of wire when ligated on labial technique and significant difference with twisted multi strand when ligated on teeth in lingual technique. Conclusion: Anchorage loss decreases with twisted multi strand wire because the friction increased between arch wire and base of bracket in both labial and lingual technique and decreased with Niti wire specially when used in lingual techniques .

Key Words: Typodont, Friction, Anchorage, Lingual, crowding.

AL-Luazy OH. Effect of Lace Back on Amount of Anchorage Loss Using Labial and Lingual Technique. (An in vitro Study). Al-Rafidain Dent J. 2013; 13(2): 366-371.

Received: 21/10/2012 Sent to Referees: 23/10/2012 Accepted for Publication: 8/1/2013

\section{INTRODUCTION}

Some authors believe that the use of light continuous force consider the most effective way to move the teeth in early stage of treatment. This is due to comfortable for the patient and minimizing the threat to anchorage come from the influence anterior bracket tip that puts demand upon anterior posterior anchorage. ${ }^{(1)}$ The canines are key stones of occlusion so the canine intended to slide distally guided by continuous wire, lace back are used to control canines and retract them sufficiently to allow alignment of incisors. Canine retracted with lace back until anterior posterior crowding was resolved. (2) Anchorage is an important consideration when planning tooth movement, un wanted tooth movement known as loss of anchorage can have determined effect on the treatment outcome. ${ }^{(3)}$ Optimal anchorage control is essential for successful orthodontic treatment. ${ }^{(4)}$ Anchorage loss is one of the side effects of orthotheropy. ${ }^{(5)}$ To obtain the desired results of closing spaces within 
arch, it is essential to control the amount of incisors retraction versus premolar and molar protraction. ${ }^{(6)}$ The orthodontist must plan how to close any space that is not devoted to relief sever crowding whether anterior teeth retraction and posterior teeth protraction. ${ }^{(7)}$ Canine retraction is one of the basic technique in orthodontic treatment. ${ }^{(8)}$ Successful retraction requires conflict control of force magnitude. ${ }^{(6)}$ Researchers have always been interested in determining efficient methods of retraction canines. ${ }^{(9)}$ Canines can be retracted by sliding, ${ }^{(9-15)}$ sliding mechanics involve moving bracket along arch wire, so friction plays a role in sliding. In sliding system, the canine is intended to slide distally guided by continuous wire. Disadvantages are represented by lack of vertical incisors control and need for increase anchorage. Typodont system can be use in orthodontic practice to show possible effects of variable factors on canine position and rate of movement during the retraction. ${ }^{(16)}$

\section{MATERIALS AND METHODS}

Materials and Supplies:

I-Typodont components Oramco, Japan.

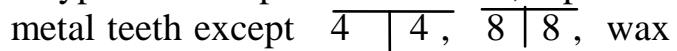
form mandibular arch with sever crowding and articulators.

II- Brackets

Stainless steel brackets Roth 0.018 inch labial conventional (Dentaurum- Germany). Stainless steel brackets Roth 0.018 inch lingual (Forestadent Germany).

III- Tubes

Buccal bondable tube (Hallimex- Germany). Lingual bondable tube (Forestadent Germany).

IV- Wires

Twisted multi strand 0.015 inch [IOS, USA]. Niti 0.012 [Hallimex, Germany]. Ligature wire 0.010 [IOS, USA]. Extension bar of rectangular wire $0.016 * 0.022$ inch [Hallimex , Germany].

V- Elastomeric model (Orthomatrix -
USA).

VI- Epoxy adhesive (USA).

VII- Digital camera (Sony - china).

VIII- Digital vernia (china).

IX- Digital water bath (MAAKE KFrance)

X- Needle holder, Tucker, Bracket clamp,

Dentaurum - Germany.

XI- Tension Gauge (France).

XII- Thermometer (China).

Methods:

Preparation of Typodont

Insert the preformed wax arch within the metal plate through pressing the waxform firmly. Then the lower mandibular teeth inserted into wax form except $\overline{4} \mid 4$,

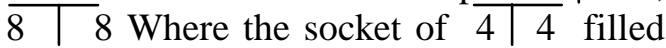
with sticky wax ,apply small amount of sticky wax aournd the roots of teeth, warm the roots and replace the teeth into wax form in a way to prevent unwanted tooth movement. All teeth sholud be fixed in a wax form according to palmer tooth no. system water bath have controlled tempreture $(54 \stackrel{\circ}{\mathrm{c}})$ typodont was immersed in the digital water bath for about (5 minute), typodont immerst in cool water about $(5 \stackrel{\circ}{\mathrm{c}})$ (Ogura et al; 1996) $^{(17)}$ the measurment and numerical value was recorded after each step of tooth movement were recorded.

Step I: Labial technique

The stainless steel Roth bracket 0.018 inch were bonded on all lower mandibular metal teeth form lower 5 to 5 except $\overline{4 / 4}$ which already extracted by special adhesive and buccal bondable tube were bonded to $6 / 6$. Incisors ligated by ligature wire figure eight and make as single unit and canine become free then two extension bar by using stainless steel wire $(0.016 * 0.022)$ inch one of them welded on arch metal parallel to the distal aspect of canine (fixed extension bar) and other on mesial aspect of lower first molar (movable extension bar) as in Figure (1) and the distance between two extension bars measured by digital vernia and considerd the control value. 

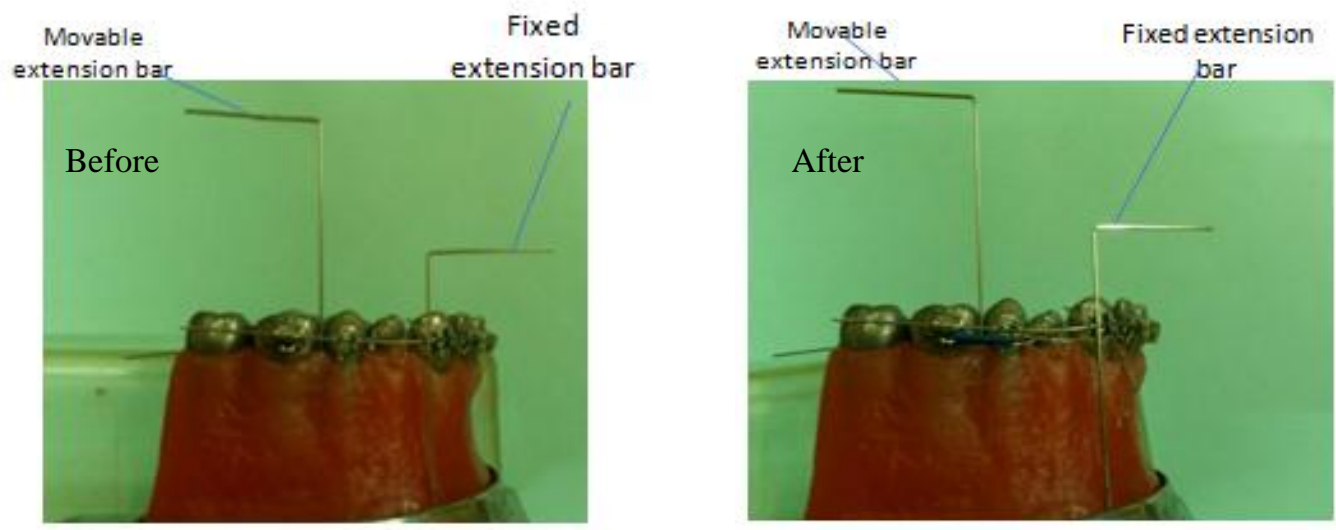

Figure (1): Labial technique before and after application of lace back.

Step II: Lingual Technique

After bonding of lingual Roth 0.018inch from $5 \mid \begin{aligned} & 5 \\ & \text { except } \overline{4}\end{aligned} \overline{4}$ and replace in their wax socket of typodont according to the manufacture instruction ( Oramco) in such way the typodont class III with sever crowding malocclusion and the socket of $4 \quad 4$ were filled with wax and $6 \mid 6$ bonded with lingual bondable tube

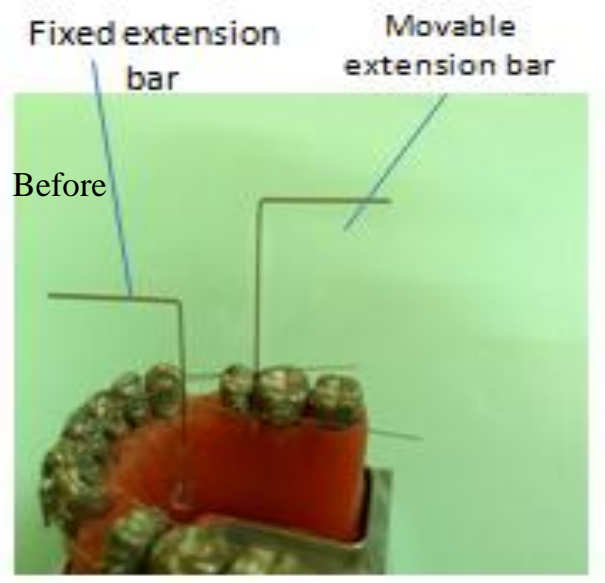

two extension bars by using stainless steel rectangular wire $(0.016 * 0.022)$ inch one of them welded in the arch metal parallel to distal aspect of canine ( fixed extension bar) and other on mesial aspect of the lower first molar as in Figure (2) and the distance between extension par measure and consider control numerical value.

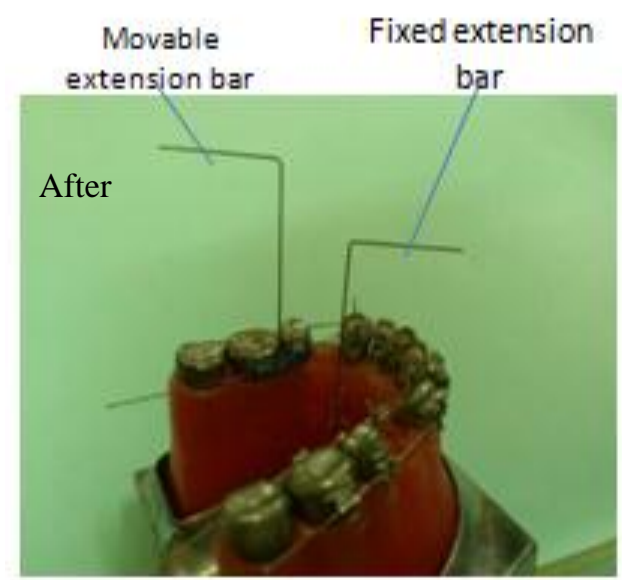

Figure (2): Lingual technique with lace back.

\section{Measuring Procedure \\ Labial technique}

canine was retracted bilaterally with active lace back (elastomeric ring with ligature wire once with twisted multi strand wire 0.015 and other with Niti wire 0.012inch). The twisted multi strand wire adjusted to labial brackets and ligated with ligature and the distance between two extension bars measured by vernia was recorded and considerd the control value. The canine were retracted by placing elastomeric ring model in the hook of buccal bondable tube as in Figure (1) and then stretched by ligature wire toward the hook of canine. The force were evaluated by tension gauge $100 \mathrm{gm}$ (1). Then, the typodont was immersed in water bath $\left(54^{\circ}\right)$ for 5 minutes. Then immersed in cooling water for 5 minutes. The new distance between two extension bars were measured. The same procedure was repeated after reposition of teeth in typodont and new waxing of teeth. 


\section{Lingual Technique}

Retraction of canine bilaterally with active lace back once with twisted multi strand 0.015 and another with Niti .Same steps of labial technique except the elastomeric ring adjusted lingually.

\section{RESULTS}

The descriptive analysis (minimum, maximum, mean and SD) for the four group are listed in Table (1) and Figure (3).

Table (1): Descriptive statistics demonstrating the effect of four groups on the amount of anchorage loss ( $\mathrm{mm}$ ).

\begin{tabular}{ccccccc}
\hline groups & N & Mean & std & Std. error & Min. & Max. \\
\hline LT & 6 & 0.6667 & 0.13663 & 0.0558 & 0.50 & 0.80 \\
LN & 6 & 1.3500 & 0.13784 & 0.0563 & 1.20 & 1.50 \\
BT & 6 & 0.4333 & 0.8165 & 0.0333 & 0.30 & 0.50 \\
BN & 6 & 0.3667 & 0.8165 & 0.0333 & 0.30 & 0.50 \\
\hline
\end{tabular}

$\mathrm{L}=$ lingual, $\mathrm{B}=$ buccal, $\mathrm{N}=$ nickel titanium, $\mathrm{T}=$ twisted arch wire

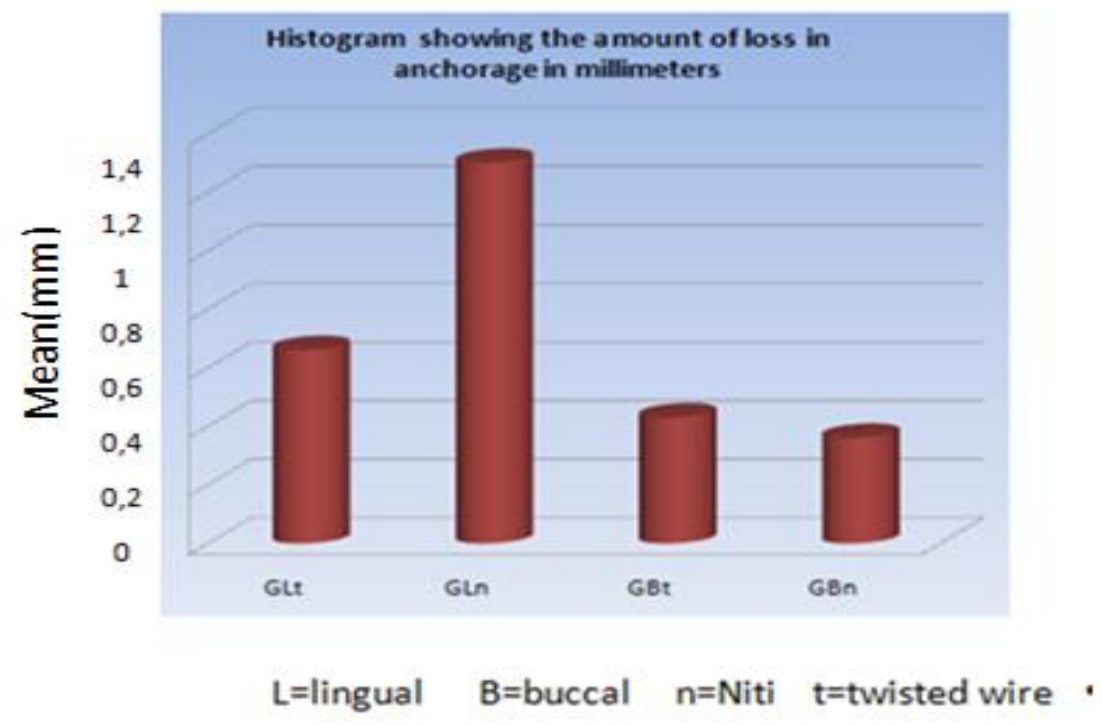

Figure (3): The amount of loss of anchorage in millimeters.

The finding of this study showed the mean of Niti wire that applied in lingual and labial technique had the highest percentage of anchorage loss was a followed by twisted multi strand that applied in the same technique, while twisted multi strand that applied in labial technique also showed the lowest value when compared with remaining groups as shown in Table (1).

Analysis of Variance (ANOVA) for the four groups showed significant difference at $p<0.01$ among them, as in the Table (2).

Table (2): ANOVA for determining difference between the effect of four groups on anchorage loss F.

\begin{tabular}{lccccc}
\hline & Sum of squares & df & Mean of square & F & Sig. \\
\hline Between groups & 3.635 & 3 & 1.212 & 95.022 & 000 \\
Within groups & 0.255 & 20 & 0.013 & & \\
Total & 3.890 & 23 & & & \\
\hline
\end{tabular}


The results of Duncan multiple range test Table (3) showed that the Niti arch wire that applied with lingual had highest rate of anchorage loss with a significant difference at $P \leq 0.05$ from other arch wire, meanwhile the Niti arch wire that applied in labial technique and twisted multi strand arch wire that applied in the same technique showed a significant difference with twisted multi strand that applied in lingual technique, but showed no significant difference at $P>0.05$ between them.

Table (3 ): Duncan's multiple range test determining difference in the effect of four groups on amount of anchorage loss (mm).

\begin{tabular}{cccc}
\hline gps & $\mathrm{N}$ & Mean \pm SEM & Duncan's gps \\
\hline BN & 6 & $0.366 \pm 0.033$ & $\mathrm{a}$ \\
BT & 6 & $0.433 \pm 0.333$ & $\mathrm{a}$ \\
LT & 6 & $0.800 \pm 0.666$ & $\mathrm{~b}$ \\
LN & 6 & $1.350 \pm 0.056$ & $\mathrm{c}$ \\
\hline
\end{tabular}

Difference litters mean significant $p \leq 0.05$.

\section{DISCUSSION}

Active lace back technique enhanced the tipping and retraction of canine specially in sever crowded cases and made the adjustment of light or low gauge wire very easily into slot of bracket in retraction of one or more upper or lower incisors teeth . This made the orthodontist reach to a preliminary canine retraction. The result of this study showed statically difference between lingual and labial technique and showed the twisted multi strand cause loss amount of anchorage of posterior teeth . This may be relate with friction between twisted multi strand wire and the slot of bracket because large contact area between slot and surface area of wire. This agreed with Gjessn, ${ }^{(18)}$ and Hart et $a l,{ }^{(19)}$ who showed successful anchorage control and the Niti base arch wire that applied in lingual technique showed high risk of anchorage loss. This agreed with Rajcich and Sadosky, ${ }^{(20)}$ and disagreed with Dawing et $a l ;{ }^{(17)}$ Vaughan et al; ${ }^{(21)}$ Ogata et al, ${ }^{(22)}$ and pizzoni et $a l,{ }^{(23)}$ Southard et al. $^{(24)}$

\section{CONCLUSION}

Active lace back has easier application for conventional labial technique than lingual technique.

* Amount of anchorage loss decreases with labial technique in comparable with lingual technique.

* In lingual technique, anchor teeth lower right molar rotate with clockwise while left molar rotate anticlockwise.
- In labial technique, the right molar rotate anticlockwise while left side rotate with clockwise .

* Tipping of canine occurs in both of techniques after sliding of canine (preliminary canine retraction).

* Rotation of anchorage teeth is more in lingual than labial and more in Niti than twisted multi strand wire.

\section{REFERENCES}

1. Mclaughlin RP, Benntt JC, Trevisi HJ. Systemized orthodontic treatment mechanics first edition, MOSBY company 2001. PP.14.13, 258, 111, 110252, 254

2. Claire N, Anthony J, I and Martyn S. An investigation in to placement of force delivery system and the intial forces applied by clinicians during space closure. Brit J orthod. (1997); 24; 127-131

3. Beattie SP:An invitro study stimulating effects daily diet and patient elastic band change compliance on orthodontic latex elastic. Angle orthod. (2004), 74(2): 234-9

4. Veziroglu F, Uckan S, Ozden UA, Arman A. Stability of zygomatic plate screw orthodontic anchorage system. Angle orthod. (2007), 78(5): 902-907

5. Geron S, Shpack N, Kandos S, Davidovitch $\mathrm{M}$, Var dimon $\mathrm{AD}$. Anchorage loss a multi factorial. Angle orthod. (2003); 73:730-737

6. Proffit WR Field HW, Ackerman JH, Baily LTJ and Camilla Tulloch JF. Contemporary orthodontics: third edi- 
tion; St. Louis Mosby company PP(2002): 3338-342, 350, 567-577

7. Staggers JA and Germane N. clinical consideration in the use of retraction mechanic. J clinorth. (1991); 25: 364369

8. Kjima $\mathrm{Y}$, Mizuno T, Umemura $\mathrm{S}$ and Fukui H. Numerical Simulation of orthodontic tooth movement produced by canine retraction spring. Dental materials J. (2007); 26(4): 561-567

9. Hayashi K, Uechi J, Muratam and Mizo guchi I. Comparison of maxillary canine retraction with eliding mechanic and retraction spring: three dimensional analysis based on mid-plated implant. Eur J orthod. (2004); 26: 585-589

10. Nanda R: Biochemical in clinical orthodontic, first edition; W.B. Saunders company, (1997). PP:6-17, 156-184, 188-125, 221-225

11. Choy K, Pae E, Kim K, Park Y, Burst one C. Control space closune with a statically determine retraction system. Angle orthod. (2002); 72(3): 191-198

12. Nisho C, damotta A, Elias C and Much $\mathrm{J}$. Invitro evaluation of frictional forces between arch wires and ceramic brackets. Am J orthod Dentofacial orthop. (2004); 25(1):56-64

13. Wichel haus A. Basic of sliding mechanics 2007. P.1-35

14.Misbah S, Bashir V, Rasool G, Arshad $\mathrm{N}$, Asrar S. Canine retraction efficacy of methods applied over the years-A systemic review. Pakistan oral and dental J. (2008); 28(2):175-180

15.Chudasama D and Jerrold L A Clinician's guide to space closure using Nickel titanium coil spring orthodontic practice; (2009):1-4

16.Loftus BP, Artun J, Nicholls JI, Alonzo TA and stoner JA: Evaluation of fric- tion during sliding tooth movement in various bracket arch wire combinations, AM J orthod Dento facial orthop. (1999); 116(3): 336-45

17. Ogura RH , Nanda RS , Puncanson MG, Sinhap and Currier G: Frictional resistance in stainless steel bracketwire combinations with effects of vertical deflections. AM J Orthod dentofacial Orthop. (1996); 109(1): 535542

18.Gjessing P. Biomechanical design and clinical evaluation of new canine retraction spring. Am J Orthod Dentofacial Orthop. 1985; 353-362

19. Hart A, Taft L, Greenberg. The effectiveness of differential momemts in establishing and maintaining anchorage. Am J Orthod Dentofacial Orthop. (1992); 102 (5): 434-442

20.Rajcicg M and Sadowsky. Efficacy of intra arch mechanics using differential moments for achieving anchorage control in extraction cases. Am J Orthod Dentofacial Orthop. (1997); 122(4): 441-448

21.Dawning A, McCabe J and Gordon P. A study of frictional forces between orthodontic brackets and archwires. $\mathrm{Br}$ JO orthod. (1994); 21 (4): 349-357

22. Vanghan JL, Duncanson MG and Nanda RS. Relattive kinetic frictional forces between sintered stainless steel bracket. Am J Orthod Dentofacial Orthop. (1995); 107 (1): 20-27

23.Pizzoni L, Ravnholt $G$ and Melsen B. Frictional forces released to self ligating bracket. Eurp J Orthod. (1998); 20(3): 283-291

24. Southard TE, Marshall SD, Grosland NM. Friction does not increase anchorage loading. AM J orthod dentofacial orthop. 2007 ; 131(3): 412-44 